\title{
Heat treatment of colostrum increases immunoglobulin G absorption efficiency in high-, medium-, and low-quality colostrum ${ }^{1}$
}

\author{
S. L. Gelsinger, S. M. Gray, C. M. Jones, and A. J. Heinrichs ${ }^{2}$ \\ Department of Animal Science, The Pennsylvania State University, University Park 16802
}

\begin{abstract}
Previous studies with heat-treated colostrum fed to neonatal calves have consistently used average-quality colostrum. Studies have not compared colostrum across a range of immunoglobulin levels. This study was conducted to investigate $\operatorname{IgG}$ absorption in neonatal dairy calves using colostrum of various qualities. Colostrum from the Pennsylvania State University dairy was collected over $2 \mathrm{yr}$ and sorted into high, medium, and low quality based on colostrometer measurement. Colostrum within each category was pooled to create 3 unique, uniform batches. Half of each batch was frozen to be fed without heat treatment. The second half of each batch was heat treated at $60^{\circ} \mathrm{C}$ for $30 \mathrm{~min}$. This process was conducted in September 2011, and repeated in June 2012. Colostrum treatments were analyzed for standard plate count, coliforms, noncoliform gram-negative bacteria, and total IgG concentration. Plasma samples were collected from 145 calves $48 \mathrm{~h}$ after birth and analyzed for $\operatorname{IgG}_{1}, \operatorname{IgG}_{2}$, total protein, and hematocrit. Colostrum quality (high, medium, or low), treatment (unheated or heat treated), and their interactions were analyzed as fixed effects, with year included as a random effect. Heat treatment significantly reduced all types of bacteria and IgG concentration. Plasma IgG concentration at $48 \mathrm{~h}$ increased linearly with the concentration of $\mathrm{IgG}$ in the colostrum that was consumed. Heat treatment of colostrum increased plasma IgG concentration by $18.4 \%$ and apparent efficiency of absorption by $21.0 \%$. Results of this study suggest that heat treatment of colostrum containing approximately 50 to $100 \mathrm{mg} \mathrm{IgG} / \mathrm{mL}$ increases absorption of IgG from colostrum.
\end{abstract}

Key words: colostrum, calf, immunoglobulin G

Received August 15, 2013.

Accepted December 20, 2013.

${ }^{1}$ This research is a component of NC-2042: Management Systems to Improve the Economic and Environmental Sustainability of Dairy Enterprises.

${ }^{2}$ Corresponding author: ajh@psu.edu

\section{INTRODUCTION}

Calves are born immunodeficient, with very low plasma levels of immunoglobulin (Elizondo-Salazar and Heinrichs, 2009). Thus, immunoglobulin must be provided to calves through feeding colostrum or colostrum-replacement products (Weaver et al., 2000). Immunoglobulin $\mathrm{G}$ is the most prevalent of the colostral antibodies and is commonly measured as an indicator of successful passive transfer of immunity (plasma IgG $>10 \mathrm{mg} / \mathrm{mL}$; Butler, 1969). Greater plasma IgG levels are correlated with reduced incidence of disease, shorter time to reach breeding weight, and potentially greater first-lactation milk production (DeNise et al., 1989; Furman-Fratczak et al., 2011). The number of dairy heifer calves experiencing failure of passive transfer has reportedly decreased from an estimated $40 \%$ in 1993, to $19.2 \%$ in 2007, according to US Department of Agriculture surveys (Beam et al., 2009). Colostrum management is often noted as a concern for neonatal dairy calf health and management (Donovan et al., 1998; Godden, 2008), and given the great production improvements observed in animals with greater passive transfer, strong impetus exists for continued improvement in this area. Current recommendations concerning colostrum management (Godden, 2008) state that calves should receive at least $3.78 \mathrm{~L}$ of high-quality $(>50$ $\mathrm{mg}$ of $\mathrm{IgG} / \mathrm{mL}$ ) colostrum to ensure successful passive transfer. At least $100 \mathrm{~g}$ of $\operatorname{IgG}$ should be supplied in the initial feeding. Absorption efficiency of IgG is greatest within $4 \mathrm{~h}$ after birth and decreases significantly after 6 $\mathrm{h}$ after birth. Recent research suggests that heat treatment of colostrum may be an additional management practice for improving IgG absorption in dairy calves (Johnson et al., 2007; Elizondo-Salazar and Heinrichs, 2009; Godden et al., 2012). The mechanism by which colostrum heat treatment improves IgG absorption has yet to be defined. It is possible that improved IgG absorption may be a result of reduced bacterial populations in heat-treated colostrum (Johnson et al., 2007). Bacteria are able to bind antibodies in the gut and thereby inhibit antibody absorption. Thus, reducing bacteria populations could increase IgG available for absorption (Acres, 1985; Saif and Smith, 1985). Others 
hypothesize that heat treatment may denature other colostral proteins that compete with IgG for absorption, thus allowing for more efficient absorption of IgG (Elizondo-Salazar and Heinrichs, 2009).

The process of heat treating colostrum at $60^{\circ} \mathrm{C}$ for 30 or 60 min has been shown to reduce SPC and coliform counts without significantly affecting viscosity or IgG concentration (Godden et al., 2006; McMartin et al., 2006). These laboratory results have been further confirmed using on-farm heat-treatment systems (Donahue et al., 2012). Heat treatment at $60^{\circ} \mathrm{C}$ for $60 \mathrm{~min}$ has also been shown to effectively eliminate Mycoplasma bovis, Listeria monocytogenes, Escherichia coli O157:H7, Salmonella enteritidis, and possibly Mycobacterium avium ssp. paratuberculosis, the causative agent of Johne's disease in cattle (Godden et al., 2006). Further studies investigating the effects of heat treatment of colostrum have shown that calves fed heat-treated colostrum have 17 to $24 \%$ greater plasma IgG concentration at $24 \mathrm{~h}$ and 20 to $34 \%$ increased IgG absorption efficiency compared with calves fed colostrum that was unheated (Johnson et al., 2007; Elizondo-Salazar and Heinrichs, 2009; Godden et al., 2012). These results indicate that feeding heat-treated colostrum to calves may be one method to improve IgG absorption and avoid failure of passive transfer while simultaneously reducing exposure to pathogens.

The IgG concentration of first-milking colostrum is very variable between cows (Baumrucker et al., 2010). However, all of the previous studies comparing IgG absorption between heat-treated and unheated colostrum used colostrum containing 60 to $75 \mathrm{mg}$ of $\mathrm{IgG} / \mathrm{mL}$ (Johnson et al., 2007; Elizondo-Salazar and Heinrichs, 2009; Godden et al., 2012). This represents average or above-average levels of IgG found in colostrum and does not represent poor- or very high-quality colostrum (Kehoe et al., 2007; Morrill et al., 2012). Many farms try to use and store only high-quality colostrum, and it is not known if this also can be improved by heat treatment. To our knowledge, no attempt has been made to measure the effects of heat treating colostrum with a wide range of IgG concentration. Therefore, the objective of this study was to determine whether similar increases in plasma IgG and absorption efficiency could be seen when calves received heat-treated or unheated colostrum of varying IgG concentration.

\section{MATERIALS AND METHODS}

All protocols for this study were approved by the institutional animal care and use committee at the Pennsylvania State University [University Park; Institutional Animal Care and Use Committee (IACUC) no. 37429]. First-milking colostrum was collected from multi- and primiparous Holstein cows in the Pennsylvania State University dairy herd into $1.89-\mathrm{L}$ plastic containers and stored at $-20^{\circ} \mathrm{C}$. Colostrum was allowed to thaw at $4^{\circ} \mathrm{C}$ and separated into 3 relative quality categories (low, medium, and high) based on colostrometer readings $48 \mathrm{~h}$ before heat treatment. Colostrum within each category was pooled and mixed to create 3 unique, uniform batches. Half of each batch was transferred into 1.89-L plastic containers and immediately stored at $-20^{\circ} \mathrm{C}$ until required for feeding (unheated colostrum). The remaining half of each colostrum batch was heated to $60^{\circ} \mathrm{C}$ and maintained for $30 \mathrm{~min}$ with continuous monitoring inside stainless steel buckets in a steam vat pasteurizer (Girton Manufacturing Co., Millville, PA). McMartin et al. (2006) and Godden et al. (2006) found no differences in SPC or coliform count when colostrum was heat treated at $60^{\circ} \mathrm{C}$ for 30 or 60 min, and heat treatment at $60^{\circ} \mathrm{C}$ for 30 min has been confirmed and used previously by our laboratory group (Elizondo-Salazar and Heinrichs, 2009, 2010). Following heat treatment, hot water in the steam vat pasteurizer was replaced with ice water to cool colostrum. Cooled colostrum was transferred into 1.89-L containers and immediately stored at $-20^{\circ} \mathrm{C}$ until required for feeding (heat-treated colostrum). This process was conducted in September 2011, and repeated in June 2012. Small aliquots of each treatment were collected from each batch after cooling as colostrum was transferred to plastic containers and stored at $-20^{\circ} \mathrm{C}$ until used for IgG and microbiological analysis.

Samples of each batch of colostrum were shipped to Prairie Diagnostic Services Laboratory (University of Saskatchewan, Saskatoon, SK, Canada) for IgG analysis via radial immunodiffusion. Each sample was cultured on duplicate plates for SPC, coliforms, and noncoliform gram-negative bacteria (Jayarao et al., 2004). Plates were incubated for $24 \mathrm{~h}$ at $32^{\circ} \mathrm{C}$ for $\mathrm{SPC}$ and $37^{\circ} \mathrm{C}$ for coliform and noncoliform gram-negative bacteria. Raw counts from duplicate plates were averaged and averages were transformed to logarithmic counts $\left[\log _{10}\right.$ (raw count +1$)$ ] to be used for statistical analysis.

Colostrum treatments were heat-treated high-, medium-, and low-quality colostrum; and unheated high-, medium-, and low-quality colostrum. One hundred and forty-five Holstein calves (70 males and 75 females) born between September and December 2011, or July and October 2012, were randomly assigned to receive colostrum from 1 treatment at birth. Calves received $1.89 \mathrm{~L}$ of colostrum within $4 \mathrm{~h}$ of birth and a subsequent $1.89 \mathrm{~L}$ of the same treatment before $8 \mathrm{~h}$ of age. According to Godden (2008), IgG absorption is most efficient within the first $4 \mathrm{~h}$ after birth. Failure of passive transfer should be avoided if a calf receives at least $100 \mathrm{~g}$ of $\operatorname{IgG}$ within $4 \mathrm{~h}$ of birth. All calves in 
this study received a minimum of approximately $100 \mathrm{~g}$ (99.4 g for calves fed low-quality, unheated colostrum) in the first feeding. Although IgG absorption efficiency would be decreased for the second colostrum feeding, it was expected to be adequate for all calves to achieve passive transfer. Colostrum was offered in 2 separate feedings to increase voluntary consumption via nipple bottle. Calves that did not consume the full treatment were fed the remaining colostrum via esophageal feeder. Birth weight was measured before colostrum feeding and used for calculating apparent efficiency of absorption (AEA; Quigley and Drewry, 1998). Blood samples were collected in evacuated glass tubes containing sodium heparin (Becton Dickinson, Franklin Lakes, NJ) $48 \mathrm{~h}$ after birth. Blood samples were centrifuged at $1,500 \times g$ for $15 \mathrm{~min}$ at $4^{\circ} \mathrm{C}$ and plasma was collected and stored at $-20^{\circ} \mathrm{C}$ for $\operatorname{IgG}$ analysis. Hematocrit was measured by centrifuging capillary tubes containing small volumes of whole blood for 3 min. Plasma total protein was measured using an optical refractometer at the time of blood sampling (SPR-T2; Atago Co. Ltd., Tokyo, Japan). The refractometer was calibrated using distilled water before each use.

Plasma concentrations of $\operatorname{IgG}_{1}$ and $\mathrm{IgG}_{2}$ were determined by ELISA. Purified $\operatorname{IgG}_{1}$ and $\operatorname{IgG}_{2}$ (Bethyl Laboratories Inc., Montgomery, TX) were diluted in Tris saline buffer containing $0.05 \%$ Tween $20(\mathrm{pH}=$ 8.0) to create a standard curve ranging from 15.6 to $1,000 \mathrm{ng} / \mathrm{mL}$. All standards were run in duplicate with each assay. Samples were tested using 4 different dilution factors to increase the probability of a sample value falling within the range of the standard concentrations. Sample values with an intraassay coefficient of variation $\leq 10.5 \%$ were accepted and averaged for analysis. Each step in the ELISA protocol was followed by $60 \mathrm{~min}$ of incubation at $20^{\circ} \mathrm{C}$, with the exception of the final enzyme reaction, and the wells were washed 5 times using the Tris saline buffer before adding the next reagent or solution. A 1:200 dilution of affinity purified bovine $\operatorname{IgG}_{1}$ or $\operatorname{IgG}_{2}$ (Bethyl Laboratories Inc.) was used to coat each well. Free ends of the bound coating antibodies were blocked using $0.05 \%$ fish gelatin solution (Sigma-Aldrich, Milwaukee, WI). Dilutions of $1: 10,000$ and $1: 15,000$ of horseradish peroxidase antibody (Bethyl Laboratories Inc.) were used for $\operatorname{IgG}_{1}$ and $\mathrm{IgG}_{2}$ horseradish peroxidase antibodies, respectively, and 3,3',5,5'-tetramethylbenzidine ELISA peroxidase substrate (Rockland Immunochemicals Inc., Gilbertsville, PA) was used in the final enzyme reaction. The enzyme reaction was allowed to proceed for 5 to $10 \mathrm{~min}$ and stopped with $0.2 \mathrm{M}$ sulfuric acid. Absorbance was read using a plate reader (VICTOR ${ }^{3}$ Multilabel Counter model 1420; PerkinElmer Life Sciences, Waltham,
MA) at a wavelength of $450 \mathrm{~nm}$. Final $\mathrm{IgG}_{1}$ and $\mathrm{IgG}_{2}$ values for plasma were added to provide an estimate of total plasma IgG concentration.

All data were analyzed using the mixed procedure in SAS (version 9.3; SAS Institute Inc., Cary, NC). Colostrum quality (high, medium, or low), treatment (unheated or heat treated), and their interactions were included as fixed effects, with year included as a random block effect to compare mean bacteria counts $(\log \mathrm{cfu} / \mathrm{mL})$ and $\operatorname{IgG}$ concentration in colostrum, as well as 48-h plasma IgG concentration, total protein concentration, and AEA. Hematocrit was offered as a covariate in the model for plasma IgG concentration, total protein concentration, and AEA, but was not significant and, thus, was removed. Linear contrasts were performed for the relationship of colostrum quality with plasma $\operatorname{IgG}$ concentration, total protein, and AEA. The Tukey adjustment was applied to pairwise comparisons in both models, and statistical significance was declared at $P<0.05$.

\section{RESULTS AND DISCUSSION}

Descriptions of the colostrum used in the current study are given in Table 1. As expected, IgG concentration was significantly different between high, medium, and low categories $(P<0.01)$. A goal of this study was to study the effect of heat treatment on IgG absorption from colostrum with initial $\mathrm{IgG}$ concentrations less than $60 \mathrm{mg} / \mathrm{mL}$ and greater than $75 \mathrm{mg} / \mathrm{mL}$. Although the low-quality colostrum used in this study would not be considered poor quality $(<50 \mathrm{mg}$ of $\mathrm{IgG} / \mathrm{mL}$; Godden, 2008), the IgG concentration was less than the $60 \mathrm{mg} / \mathrm{mL}$ used in previous studies. In addition, IgG concentration in high-quality colostrum was greater than $75 \mathrm{mg} / \mathrm{mL}$. No differences were observed in the bacterial populations between colostrum quality categories before heat treatment. Heat treatment of colostrum at $60^{\circ} \mathrm{C}$ for 30 min significantly decreased SPC, and effectively eliminated coliform and noncoliform gram-negative bacteria $(P<0.05)$. Previous studies conducted in a laboratory setting and on farm also reported reductions in bacterial populations following heat treatment at $60^{\circ} \mathrm{C}$ for 30 or 60 min (Godden et al., 2006; Elizondo-Salazar et al., 2010; Donahue et al., 2012).

Heat treatment also caused an overall decrease in IgG concentration $(P=0.05)$, although none of the pairwise comparisons were significant after the Tukey adjustment. The decreases in IgG concentration observed in the present study were $6.5,0.9$, and $3.8 \mathrm{mg} / \mathrm{mL}$ for high-, medium-, and low-quality colostrum, respectively, which are within the numerical ranges reported 
Table 1. Immunoglobulin G concentration $(\mathrm{mg} / \mathrm{mL})$ and bacteria counts $(\log \mathrm{cfu} / \mathrm{mL})$ in colostrum before and after heat treatment $\left(60^{\circ} \mathrm{C} \text { for } 30 \mathrm{~min}\right)^{1,2}$

\begin{tabular}{lllll}
\hline Colostrum & $\operatorname{IgG}$ & $\mathrm{SPC}$ & $\mathrm{CC}$ & $\mathrm{NC}$ \\
\hline High quality & & & & \\
Unheated & $98.8^{\mathrm{a}}$ & $4.6^{\mathrm{a}}$ & 1.9 & $3.2^{\mathrm{a}}$ \\
$\quad$ Heat treated & $92.3^{\mathrm{a}}$ & $2.1^{\mathrm{ab}}$ & 0.0 & $0.0^{\mathrm{b}}$ \\
Medium quality & & & & \\
$\quad$ Unheated & $71.9^{\mathrm{b}}$ & $4.1^{\mathrm{a}}$ & 1.6 & $2.7^{\mathrm{a}}$ \\
Heat treated & $71.0^{\mathrm{b}}$ & $1.3^{\mathrm{b}}$ & 0.0 & $0.0^{\mathrm{b}}$ \\
Low quality & & & & \\
Unheated & $56.4^{\mathrm{c}}$ & $4.6^{\mathrm{a}}$ & 1.6 & $3.8^{\mathrm{a}}$ \\
Heat treated & $52.6^{\mathrm{c}}$ & $1.3^{\mathrm{b}}$ & 0.0 & $0.0^{\mathrm{b}}$ \\
\hline
\end{tabular}

${ }^{\mathrm{a}-\mathrm{c}}$ Values within a column with different superscript letters are significantly different $(P<0.05)$.

${ }^{1} \mathrm{SPC}=$ standard plate count $\mathrm{CC}=$ coliform count; $\mathrm{NC}=$ noncoliform, gram-negative count.

${ }^{2}$ Least squares means represent samples collected at the time of heat treatment in 2011 and $2012(\mathrm{n}=12 ;, 6$ treatments replicated in $2 \mathrm{yr})$.

by others (Godden et al., 2006; McMartin et al., 2006; Elizondo-Salazar et al., 2010). Elizondo-Salazar et al. (2010) reported a significant decrease in $\mathrm{IgG}_{1}$, with no change in $\mathrm{IgG}_{2}$ when colostrum was heat treated at $60^{\circ} \mathrm{C}$ for 30 min. Other studies (Godden et al., 2006; McMartin et al., 2006) have reported numerical changes of IgG concentration within individual colostrum batches, ranging from a $27.7 \mathrm{mg} / \mathrm{mL}$ decrease to a $13.8 \mathrm{mg} /$ $\mathrm{mL}$ increase following heat treatment; however, these changes were not significant in those studies.

The significant decrease in IgG concentration observed in the current study may have resulted from the large change seen in the colostrum with the highest IgG concentration, although no interaction was detected between heat treatment and colostrum IgG level. One on-farm study found 9.8 and $6.7 \mathrm{mg} / \mathrm{mL}$ decreases in IgG when initial concentrations were $\geq 80 \mathrm{mg} / \mathrm{mL}$ and between 70 and $79 \mathrm{mg} / \mathrm{mL}$, respectively. But IgG concentration only decreased by $1.0 \mathrm{mg} / \mathrm{mL}$ when initial concentration was between 50 and $59 \mathrm{mg} / \mathrm{mL}$ (Donahue et al., 2012). Other investigations (Godden et al., 2006; McMartin et al., 2006) have found similar results. Godden et al. (2006) reported 5.8 and 9.3 $\mathrm{mg} / \mathrm{mL}$ reductions in $\mathrm{IgG}$ concentration in colostrum batches with IgG concentration $>75 \mathrm{mg} / \mathrm{mL}$; however, $\operatorname{IgG}$ concentration was not different before and after heat treatment in batches of lower-quality colostrum. Similarly, another study reported a loss of $4.6 \mathrm{mg} / \mathrm{mL}$ in IgG concentration with an initial concentration $\geq 73$ $\mathrm{mg} / \mathrm{mL}$; whereas colostrum with an initial IgG concentration $<73 \mathrm{mg} / \mathrm{mL}$ lost $0.79 \mathrm{mg} / \mathrm{mL}$ during heat treatment (McMartin et al., 2006). The highest-quality colostrum in the current study contained $98.8 \mathrm{mg}$ of $\mathrm{IgG} / \mathrm{mL}$ before heat treatment. This level decreased $6.5 \mathrm{mg} / \mathrm{mL}$ during heat treatment to $92.3 \mathrm{mg} / \mathrm{mL}$.
However, the IgG concentration of heat-treated, highquality colostrum remained significantly greater than that of medium-quality colostrum $(P<0.05)$.

Values for plasma $\operatorname{IgG}_{1}, \operatorname{IgG}_{2}$, total $\operatorname{IgG}$, AEA, and total protein are shown in Table 2. Regardless of heat treatment, plasma concentrations of $\operatorname{IgG}_{1}$, total $\operatorname{IgG}$, and total protein increased linearly $(P<0.05)$ with colostrum quality. Heat treatment of colostrum also increased plasma concentrations of $\operatorname{IgG}_{1}, \mathrm{IgG}_{2}$, total IgG, and total protein $(P<0.05)$, and increased AEA $(P<0.05)$. Mean total plasma IgG concentrations $(\mathrm{LSM} \pm \mathrm{SE})$ were $23.3 \pm 3.1,27.5 \pm 3.1,18.1 \pm 3.2$, $22.5 \pm 3.2,13.3 \pm 3.2$, and $14.8 \pm 3.3$ for high-quality unheated and heat-treated, medium-quality unheated and heat-treated, and low-quality unheated and heattreated colostrum, respectively. Seventeen calves (12\%) experienced failure of passive transfer (48-h plasma IgG concentration $<10.0 \mathrm{mg} / \mathrm{mL}$ ). Of these, 11 received low-quality ( 5 heat-treated and 6 unheated), 5 received medium-quality (2 heat-treated and 3 unheated), and 1 received heat-treated, high-quality colostrum. As shown in Table 2, calves fed heat-treated, high-quality colostrum achieved the greatest plasma IgG concentration, and the lowest plasma $\operatorname{IgG}$ concentrations were observed in calves fed unheated, low-quality colostrum. The most interesting result is seen in calves fed medium-quality colostrum. Plasma IgG concentration in calves fed heat-treated, medium-quality colostrum was similar to the concentration seen in calves fed highquality colostrum, whereas plasma IgG concentration in calves fed unheated, medium-quality colostrum was significantly lower than that of calves fed high-quality colostrum. Therefore, heat treatment of colostrum within the range of 50 to $100 \mathrm{mg}$ of $\mathrm{IgG} / \mathrm{mL}$ may be able to overcome effects of feeding colostrum of lower quality.

Total protein concentrations from the current study are reported in Table 2. Mean total protein concentrations were $8.0,7.9,7.4,7.5,6.8$, and 7.4 for high-quality unheated and heat-treated, medium-quality unheated and heat-treated, and low-quality unheated and heattreated colostrum, respectively. The standard errors were the same for all total protein mean estimates (SE $=1.0$ ). Total protein concentration increased linearly with colostrum quality and was greater in calves that received heat-treated colostrum. However, a significant interaction existed between colostrum quality and treatment. The effect of heat treatment was less pronounced when calves received high-quality colostrum compared with when calves received low-quality colostrum. Total protein concentration increased $0.6 \mathrm{~g} / \mathrm{dL}$ when low-quality colostrum was heat treated, whereas heat treatment of high-quality colostrum did not signif- 
Table 2. Least squares means estimates for 48-h plasma IgG concentration and apparent efficiency of absorption (AEA) of IgG in calves fed unheated or heat-treated $\left(60^{\circ} \mathrm{C}\right.$ for $\left.30 \mathrm{~min}\right)$ colostrum of high, medium, or low quality

\begin{tabular}{|c|c|c|c|c|c|c|c|c|}
\hline \multirow[b]{2}{*}{ Item } & \multicolumn{3}{|c|}{ Unheated } & \multicolumn{3}{|c|}{ Heat treated } & \multicolumn{2}{|c|}{$P$-value ${ }^{1}$} \\
\hline & High & Medium & Low & High & Medium & Low & $\mathrm{T}$ & $\mathrm{Q}$ \\
\hline $\mathrm{IgG}_{1}(\mathrm{mg} / \mathrm{mL})$ & $22.4^{\mathrm{ab}}$ & $17.4^{\mathrm{bc}}$ & $12.9^{\mathrm{c}}$ & $26.4^{\mathrm{a}}$ & $21.5^{\mathrm{abc}}$ & $15.4^{\mathrm{c}}$ & 0.03 & $<0.01$ \\
\hline $\mathrm{IgG}_{2}(\mathrm{mg} / \mathrm{mL})$ & $0.8^{\mathrm{ab}}$ & $0.7^{\mathrm{abc}}$ & $0.4^{\mathrm{c}}$ & $1.1^{\mathrm{a}}$ & $0.9^{\mathrm{a}}$ & $0.5^{\mathrm{bc}}$ & 0.03 & $<0.01$ \\
\hline Total $\mathrm{IgG}^{2}(\mathrm{mg} / \mathrm{mL})$ & $23.3^{\mathrm{ab}}$ & $18.1^{\mathrm{bc}}$ & $13.3^{\mathrm{c}}$ & $27.5^{\mathrm{a}}$ & $22.5^{\mathrm{ab}}$ & $14.8^{\mathrm{c}}$ & 0.03 & $<0.01$ \\
\hline $\operatorname{AEA}^{3}(\%)$ & 23.1 & 26.9 & 24.5 & 30.9 & 30.2 & 28.4 & 0.01 & 0.66 \\
\hline
\end{tabular}

${ }^{\mathrm{a}-\mathrm{c}}$ Values within a row with different superscript letters are significantly different $(P<0.05)$

${ }^{1} \mathrm{~T}=$ treatment (unheated vs. heat treated); $\mathrm{Q}=$ colostrum quality (high, medium, or low).

${ }^{2}$ Total $\operatorname{IgG}=\operatorname{IgG}_{1}+\operatorname{IgG}_{2}$.

${ }^{3}$ Calculated according to Quigley and Drewry (1998) for total IgG.

icantly alter total protein concentration. Total protein and IgG concentration are positively correlated (Tyler et al., 1996); thus, calves with greater total protein concentration are expected to have greater IgG concentration as well. Data from calves fed low-quality colostrum supports the correlation reported by Tyler et al. (1996). However, $\operatorname{IgG}$ concentration continues to increase with heat treatment of medium- and high-quality colostrum, whereas total protein concentration appears to reach a plateau when medium- and high-quality colostrum are fed and is no longer affected by heat treatment of colostrum. Elizondo-Salazar and Heinrichs (2009) reported greater $\operatorname{IgG}$ concentration in calves fed heat-treated colostrum compared with calves that received unheated colostrum, despite similar serum total protein concentration. The interaction effect of colostrum quality and heat treatment on total protein concentration observed in the current study may partially explain this result. Colostrum used in their study contained 76.4 and 74.4 $\mathrm{mg}$ of $\mathrm{IgG} / \mathrm{mL}$ before and after heat treatment, respectively, similar to the medium-quality colostrum used in the current study. The current study measured concentrations of total protein and IgG in plasma rather than serum; however, because both IgG and total protein were measured in plasma, this methodological difference should not affect the correlation between the 2 concentrations. These results, combined with results from Elizondo-Salazar and Heinrichs (2009), provide some support for the hypothesis that heat treatment of colostrum increases IgG absorption by affecting absorption of other colostral proteins.

Previous studies (Johnson et al., 2007; ElizondoSalazar and Heinrichs, 2009; Godden et al., 2012) have also reported increased IgG absorption in calves when colostrum was heat treated. Johnson et al. (2007) reported a $19 \%$ increase in serum IgG concentration $24 \mathrm{~h}$ after feeding when calves received heat-treated colostrum of average quality (initial $\mathrm{IgG}$ concentration $=72.6 \mathrm{mg} / \mathrm{mL}$ ) compared with calves fed unheated colostrum. Similarly, results from Elizondo-Salazar and Heinrichs (2009) indicated that calves receiving heattreated colostrum (initial IgG concentration $=76.43$ $\mathrm{mg} / \mathrm{mL}$ ) attained plasma $\mathrm{IgG}_{1}$ and $\mathrm{IgG}_{2}$ concentrations 16 and $18 \%$ higher, respectively, at $48 \mathrm{~h}$ of age compared with calves fed unheated colostrum. In the present study, despite a significant reduction in colostrum IgG concentration following heat treatment $(P$ $<0.05$ ), heat treatment of colostrum increased plasma total IgG concentration by $18.4 \%$ and AEA by $21.0 \%$. Mean AEA values (LSM $\pm \mathrm{SE}$ ) were $23.1 \pm 4.4,30.9 \pm$ $4.4,26.9 \pm 4.5,30.2 \pm 4.5,24.5 \pm 4.6$, and $28.4 \pm 4.6$ for high-quality unheated and heat-treated, mediumquality unheated and heat-treated, and low-quality unheated and heat-treated colostrum, respectively. Within each quality level, heat treatment increased plasma total IgG concentration by 15,20 , and $10 \%$ for calves fed high-, medium-, and low-quality colostrum, respectively. The greatest benefit of heat treatment appears to be realized in medium-quality colostrum by increasing absorption efficiency and decreasing the risk of failure of passive transfer when colostrum of lower quality is fed.

\section{CONCLUSIONS}

Heat treatment of colostrum containing approximately 50 to $100 \mathrm{mg}$ of $\mathrm{IgG} / \mathrm{mL}$ increased absorption of IgG and this effect was more pronounced using colostrum of greater initial IgG concentration. Total protein concentration was also increased in calves that received heat-treated colostrum; however, this effect diminished as initial colostrum IgG concentration increased. These combined results offer support for the hypothesis that heat treatment of colostrum increases IgG absorption by decreasing absorption of non-IgG colostral proteins. Further research must be done to investigate the effects of heat treatment on other colostral proteins and subsequent effects on calf health. 


\section{REFERENCES}

Acres, S. D. 1985. Enterotoxigenic Escherichia coli infections in newborn calves: A review. J. Dairy Sci. 68:229-256.

Baumrucker, C. R., A. M. Burkett, A. L. Magliaro-Macrina, and C. D. Dechow. 2010. Colostrogenesis: Mass transfer of immunoglobulin $\mathrm{G}_{1}$ into colostrum. J. Dairy Sci. 93:3031-3038.

Beam, A. L., J. E. Lombard, C. A. Kopral, L. P. Garber, and A. L. Winter. 2009. Prevalence of failure of passive transfer of immunity in newborn heifer calves and associated management practices on US dairy operations. J. Dairy Sci. 92:3973-3980.

Butler, J. E. 1969. Bovine immunoglobulins: A review. J. Dairy Sci. 52:1895-1909.

DeNise, S. K., J. D. Robison, G. H. Stott, and D. V. Armstrong. 1989. Effects of passive immunity on subsequent production in dairy heifers. J. Dairy Sci. 72:552-554.

Donahue, M., S. M. Godden, R. Bey, S. Wells, J. M. Oakes, S. Sreevatsan, J. Stabel, and J. R. Fetrow. 2012. Heat treatment of colostrum on commercial dairy farms decreases colostrum microbial counts while maintaining colostrum immunoglobulin $\mathrm{G}$ concentrations. J. Dairy Sci. 95:2697-2702.

Donovan, G. A., I. R. Dohoo, D. M. Montgomery, and F. L. Bennett. 1998. Associations between passive immunity and morbidity and mortality in dairy heifers in Florida, USA. Prev. Vet. Med. 34:31-46.

Elizondo-Salazar, J. A., and A. J. Heinrichs. 2009. Feeding heat-treated colostrum to neonatal dairy heifers: Effects on growth characteristics and blood parameters. J. Dairy Sci. 92:3265-3273.

Elizondo-Salazar, J. A., B. M. Jayarao, and A. J. Heinrichs. 2010. Effect of heat treatment of bovine colostrum on bacterial counts, viscosity, and immunoglobulin G concentration. J. Dairy Sci. 93:961-967.

Furman-Fratczak, K., A. Rzasa, and T. Stefaniak. 2011. The influence of colostral immunoglobulin concentration in heifer calves' serum on their health and growth. J. Dairy Sci. 94:5536-5543.

Godden, S. 2008. Colostrum management for dairy calves. Vet. Clin. North Am. Food Anim. Pract. 24:19-39.

Godden, S., S. McMartin, J. Feirtag, J. Stabel, R. Bey, S. Goyal, L. Metzger, J. Fetrow, S. Wells, and H. Chester-Jones. 2006. Heat- treatment of bovine colostrum. II: Effects of heating duration on pathogen viability and immunoglobulin G. J. Dairy Sci. 89:34763483.

Godden, S. M., D. J. Smolenski, M. Donahue, J. M. Oakes, R. Bey, S. Wells, S. Sreevatsan, J. Stabel, and J. Fetrow. 2012. Heat-treated colostrum and reduced morbidity in preweaned dairy calves: Results of a randomized trial and examination of mechanisms of effectiveness. J. Dairy Sci. 95:4029-4040.

Jayarao, B. M., S. R. Pillai, A. A. Sawant, D. R. Wolfgang, and N. V. Hegde. 2004. Guidelines for monitoring bulk tank milk somatic cell and bacterial counts. J. Dairy Sci. 87:3561-3573.

Johnson, J. L., S. M. Godden, T. Molitor, T. Ames, and D. Hagman. 2007. Effects of feeding heat-treated colostrum on passive transfer of immune and nutritional parameters in neonatal dairy calves. J. Dairy Sci. 90:5189-5198.

Kehoe, S. I., B. M. Jayarao, and A. J. Heinrichs. 2007. A survey of bovine colostrum composition and colostrum management practices on Pennsylvania dairy farms. J. Dairy Sci. 90:4108-4116.

McMartin, S., S. Godden, L. Metzger, J. Feirtag, R. Bey, J. Stabel, S. Goyal, J. Fetrow, S. Wells, and H. Chester-Jones. 2006. Heat treatment of bovine colostrum. I: Effects of temperature on viscosity and immunoglobulin G level. J. Dairy Sci. 89:2110-2118.

Morrill, K. M., E. Conrad, A. Lago, J. Campbell, J. Quigley, and H. Tyler. 2012. Nationwide evaluation of quality and composition of colostrum on dairy farms in the United States. J. Dairy Sci. 95:3997-4005.

Quigley, J. D., III, and J. J. Drewry. 1998. Nutrient and immunity transfer from cow to calf pre- and postcalving. J. Dairy Sci. 81:2779-2790

Saif, L. J., and K. L. Smith. 1985. Enteric viral infections of calves and passive immunity. J. Dairy Sci. 68:206-228.

Tyler, J. W., D. D. Hancock, S. M. Parish, D. E. Rea, and T. E. Besser. 1996. Evaluation of 3 assays for failure of passive transfer in calves. J. Vet. Intern. Med. 10:304-307.

Weaver, D. M., J. W. Tyler, D. C. VanMetre, D. E. Hostetler, and G. M. Barrington. 2000. Passive transfer of colostral immunoglobulins in calves. J. Vet. Intern. Med. 14:569-577. 